\title{
"NO-STRIKE" CLAUSES IMPLIED FROM ARBITRATION AGREEMENTS: APPLICATION TO STRIKES AGAINST UNFAIR LABOR PRACTICES*
}

Collective bargaining agreements often include clauses providing for arbitration of future disputes arising between union and employer. ${ }^{1}$ Under statutes enacted in many jurisdictions, ${ }^{2}$ these clauses may be judicially enforced by two methods unavailable at common law. Thus, courts may award specific performance of arbitration, ${ }^{3}$ or they may stay judicial proceedings until the parties arbitrate as provided in their contract. ${ }^{4}$ In contrast to these statutory

*Local 25, Teamsters Union, AFL v. W. L. Mead, Inc., 230 F.2d 576 (1st Cir. 1956).

1. See Moore \& Nix, Arbitration Provisions in Collective Agreements, 1952, 76 MoNTH. LAB. Rev. 261, 262 (1953). Provisions for arbitration of future disputes are frequently contained in commercial contracts. Sturges, Comarerctal Arbitrations AND Awards $\$ 13$ (1930) (hereinafter cited as STuRges). For discussion of types of clauses providing for arbitration of future disputes, see $i d$. $\$ 46 ; 6$ WILLISTON, Contracts $\$ 1924$ (rev. ed. 1938).

2. State: E.g., Cal. Code Civ. Proc. $\$ \$ 1282,1284$ (Deering 1953), Levy v. Superior Court, 15 Cal. 2d 692, 104 P.2d 770 (1940); Mass. Ans. Laws c. 251, $\$ \$ 14-22$ (1956), Textile Workers Union, CIO v. American Thread Co., 113 F. Supp. 137, 141 (D. Mass. 1953) (interpreting Mass. law) ; N.Y. Civ. Prac. Act $\$ \$ 1450-51$; Pa. Stat. Ans. tit. 5, $\$ \S 162,163$ (Purdon Supp. 1956) ; see, generally, Gregory \& Orlikoff, The Enforcement of Labor Arbitration Agreements, 17 U. CHI. L. REv. 233, 238-45 (1950).

Federal: Whether the United States Arbitration Act $\$ 3,9$ U.S.C. $\$ 3$ (1952), providing for stays of suits pending arbitration as agreed upon by the parties, applies to collective bargaining contracts is unclear. Compare Lewittes \& Sons v. United Furniture Workers, CIO, 95 F. Supp. 851 (S.D.N.Y. 1951), with International Union United Furniture Workers v. Colonial Hardwood Flooring Co., 168 F.2d 33 (4th Cir. 1948). Problems also exist with grants of specific performance of arbitration under either the arbitration statute, 9 U.S.C. $\$ 4$ (1952), or LMRA $\$ 301,61$ STAT. 156 (1947), 29 U.S.C. $\$ 185$ (1952). Compare Local 205, United Elec. Workers v. General Elec. Co., 233 F.2d 85 (1st Cir. 1956) and Textile Workers Union, Clo v. American Thread Co., 1.13 F. Supp. 137 (D. Mass. 1953), with Lincoln Mills v. Textile Workers Union, CIO, 230 F.2d 81, 86, 88 (5th Cir. 1956). See Mendelsohn, Enforceability of Arbitration Agreements Under Taft-Hartley Section 301, 66 YALE L.J. 167 (1956).

3. State lazw: See Textile Workers Union, CIO v. American Thread Co., 113 F. Supp. 137, 141 (D. Mass. 1953) (alternative holding interpreting Mass. law); Local 411, United Elec. Workers, CIO v. National Pneumatic Co., 134 N.J.L. 349, 48 A.2d 295 (Sup. Ct. 1946) ; Philadelphia Marine Trade Ass'n v. Local 1291, Int'l Longshoremen's Ass'n, 382 Pa. 326, 115 A.2d 733 (1955) (union enjoined from failing to arbitrate as prescribed in contract).

Federal law: See, e.g., Textile Workers Union, CIO v. Aleo Mfg. Co., 94 F. Supp. 626 (M.D.N.C. 1950); United Office Workers, CIO v. Monumental Life Ins. Co., S8 F. Supp. 602, 607 (E.D. Pa. 1950).

Where no statute is applicable, specific enforcement of arbitration agreements is denied. See Lincoln Mills v. Textile Workers Union, CIO, 230 F.2d 81 (5th Cir. 1956); cf. STURGES $\$ 23$.

4. State law: See Miroflex Products Co. v. Rosenthal, 192 Misc. 673, 80 N.Y.S.2d 788 (Sup. Ct. 1948).

Federal law: See, e.g., Lewittes \& Sons v. United Furniture Workers, CIO, 95 F. Supp. 
remedies, an award of damages was a party's sole means of redress at common law for breach of an agreement to arbitrate. ${ }^{\mathbf{5}}$ But because courts uniformly indicated that damages would be limited to amounts expended in preparing for arbitration, ${ }^{6}$ this remedy was of limited effectiveness. Consequently, few damage suits have been brought on arbitration agreements of any sort, ${ }^{7}$ and apparently none on arbitration clauses in collective bargaining contracts. Recently, however, the Court of Appeals for the First Circuit, forging a new rationale to avoid the common law limitation, upheld an award of substantial damages for breach of an arbitration clause in a collective bargaining agreement.

The arbitration clause in Local 25, Teansters Union, AFL v. W. L. Mead, Inc. ${ }^{8}$ provided that arbitration should be the exclusive means of adjudicating all disputes. ${ }^{D}$ A controversy arose between the employer and union over the down-grading of an employee. Without submitting the dispute to arbitration, the union struck. ${ }^{10}$ The employer then brought an action under section 301 of the Labor Management Relations Act in a federal district court, seeking as damages profits lost as a result of the strike. ${ }^{11}$ The employer argued that the

S51 (S.D.N.Y. 1951); United Office Workers, CIO v. Monumental Life Ins. Co., 88 F. Supp. 602, 605 (E.D. Pa. 1950).

Stays of court proceedings are unavailable where there is no statute. See Berkovitz v. Arbib \& Houlberg, Inc., 230 N.Y. 261, 130 N.E. $28 \&$ (1921). Cf. Sturges \& 23.

5. See Gregory \& Orlikoff, supra note 2, at 236; Thomas W. Finucane Co. v. Board of Educ., 190 N.Y. 76, 83, 82 N.E. 737, 739 (1907) (dictum). But see Cocalis v. Nazlides, 308 Ill. 152, 139 N.E. 95 (1923).

6. Under an agreement to arbitrate future disputes, where no action was taken beyond a demand and refusal to arbitrate, only nominal damages would be recoverable for breach. Munson v. Straits of Dover S.S. Co., 99 Fed. 787 (S.D.N.Y.), aff'd, 102 Fed. 926 (2d Cir. 1900). The rule is the same, however, for breaches of agreements to arbitrate existing disputes. Compare Munson v. Straits of Dover S.S. Co., supra, with McKenzie v. Mitchell, 123 Ga. 72, 51 S.E. 34 (1905); Call v. Hagar, 69 Me. 521 (1879); Pond v. Harris, 113 Mass. 114 (1873).

7. See Sturges $\$ 22$.

8. 230 F.2d 576 (1st Cir. 1956), affirming 126 F. Supp. 466 (D. Mass. 1954) and 129 F. Supp. 313 (D. Mass. 1.955).

9. Id. at 582. The arbitration clause read in part:

"Should any dispute, grievance or complaint arise during the life of the agreement which the Business Representative fails to adjust, the dispute, grievance or complaint shall be referred to the Arbitration Panel which Panel shall be the exclusive means of adjudicating all disputes."

10. Id. at 583 .

11. 61 Srat. 156 (1947), 29 U.S.C. \& 185 (1952). Relevantly, \& 301 reads:

"(a) Suits for violation of contracts between an employer and a labor organization representing employees in an industry affecting commerce ... may be brought in any district court of the United States having jurisdiction of the parties, without respect to the amount in controversy or without regard to the citizenship of the parties."

The employer also sought to recover expenses he had incurred during the strike in keeping his business ready to resume full-scale operations. See W. L. Mead, Inc. v. Local 25, Teamsters Union, AFL, 129 F. Supp. 313, 317 (D. Mass. 1955). 
strike was in breach of a no-strike clause impliedly contained in the bargaining contract's arbitration clause. ${ }^{12}$

Affirming the district court's award of substantial damages, the First Circuit interpreted the arbitration clause to include an implied agreement not to strike. ${ }^{13}$ The appellate court reasoned that the parties had meant to prohibit strikes on all issues to which the arbitration clause applied because a strike would be a substitute for arbitration. Since arbitration was agreed on as the exclusive means of settling all disputes, the existence of a right to strike was incompatible with the terms of the contract as a matter of law. ${ }^{14}$ Alternatively, the appellate court declared that parol evidence disclosed that the parties had intended the arbitration clause to prohibit strikes. ${ }^{15}$ During negotiations over the contract, the union had rejected the employer's proposal to include an express no-strike clause in the contract. The district court had found, however, that this evidence did not indicate the union intended to protect its right to strike, ${ }^{16}$ but more likely that it disavowed liability for wildcat strikes. ${ }^{17}$ The court had further found that testimony on this point showed only the union's opposition to an express no-strike clause, not its rejection of an implied nostrike prohibition as well. ${ }^{18}$

The First Circuit rationale should not stand as precedent in future cases of similar nature. In Mead the parties had stipulated that the cause of the strike was immaterial. ${ }^{19}$ In other cases, the issues should be framed, not solely in terms of contract doctrine but as well in relation to the different types of strikes that may arise and to other existing theories for enforcing a union's contractual responsibility. Strikes may be categorized generally as one of two types: strikes of an economic nature and strikes against an unfair labor practice committed by the employer. The former includes strikes to modify an existing contract as well as other kinds of work stoppages over economic dis-

12. See W. L. Mead, Inc. v. Local 25, Teamsters Union, AFL, 126 F. Supp. 466,467 (D. Mass. 1954), noted in 68 HARv. L. Rev. 1472 (1955).

13. 230 F.2d at 583.

14. Ibid. See 126 F. Supp. at 467.

15. 230 F.2d at 583 .

16. 126 F. Supp. at 469.

17. Id. at 469-70. But see, United Constr. Workers v. Haislip Baking Co., 223 F.2d 872 (4th Cir.), cert. denied, 350 U.S. 847 (1955), indicating that unions have never been held liable for strikes which they did not authorize or ratify. Cf. Garmeada Coal Co. v. International Union of United Mine Workers, 122 F. Supp. 512 (E.D. Ky. 1954), aff'd, 230 F.2d 945 (6th Cir. 1956) (international union not liable for strike although it expressly agreed to exercise best efforts to prevent stoppages). Haislip and Garmeada thus make it improbable that a union would reject an express no-strike clause because it feared liability for wildcat strikes.

18. 126 F. Supp. at $469-70$.

19. Id. at 467 . The First Circuit itself merely declared that the dispute causing the strike was arbitrable under the contract. 230 F.2d at 583 .

However, the NLRB did indicate, subsequent to the district court's opinion, that the strike was probably not an unfair labor practice strike. W. L. Mead, Inc., 113 N.L.R.B. 1040, 1044 (1955), noted in 54 MrCH. L. Rev. 570 (1956). 
putes, such as an employer's interpretation of his own contract powers. Strikes to modify the provisions of an existing contract are considered to violate those provisions themselves and consequently to breach the contract as a matter of law. ${ }^{20}$ While no decisions are found awarding damages for these walkouts, unions should be held accountable in damages under a simple contract theory regardless of whether the bargaining agreement includes an arbitration clause. The First Circuit's rationale thus would probably have been unnecessary to enforce the union's liability for damages were the strike in Mead one to modify a term of the contract. In other types of economic strikes, different factors may be operative which demand closer scrutiny of the Mead decision. Finally, the First Circuit's decision applies to unfair labor practice strikes as well as to economic strikes. Under the court's reasoning, the implied no-strike clause covered all arbitrable disputes. Under arbitration clauses as broad as that in Mead all disputes, including those arising out of alleged unfair labor practices, may be arbitrable. ${ }^{21}$ Consequently, Mead would bar unfair labor practice strikes whenever the arbitration clause was held applicable to the dispute. The decision is thus significant as a new means for controlling such strikes, and the restriction it imposes should be considered in the context of existing judicial and statutory attitudes toward this important union weapon.

Analysis of a recent Supreme Court opinion suggests that courts faced with an unfair labor practice strike when parties are governed by a bargaining agreement with a broad arbitration clause should reject the Mead rationale. In Mastro Plastics Corp. v. NLRB 22 the Court upheld a Labor Board order reinstating workers who had struck against unfair labor practices. Rejecting the employer's defense that the workers had breached an express no-strike clause in the bargaining contract, the Court interpreted the clause to bar only economic strikes. In its view, only if unfair labor practice strikes were specifi-

20. See NLRB v. Sands Mfg. Co., 306 U.S. 332, 344 (1939). Sands upheld an employer's refusal to rehire workers who had struck to modify the bargaining contract, although the contract apparently did not contain an express no-strike clause. See reference to Sands in Local 25, Teamsters Union, AFL v. W. L. Mead, Inc., 230 F.2d 576, 584 (1st Cir. 1956). The Supreme Court declared: "[The employer] . . . rightly understood that the men were irrevocably committed [by their strike] not to work in accordance with their contract. It was at liberty to treat them as having severed their reiations with the company because of their breach. ..." See also NLRB v. Draper Corp., 145 F.2d 199, 204 (4th Cir. 1944), interpreting Sands to mean that the strike was a breach of contract.

21. In re Consolidated Aircraft Corp., 47 N.L.R.B. 694, 706 (1943), modified on other grourds, Consolidated Aircraft Corp. v. NLRB, 141 F.2d 785, 788 (9th Cir. 1944).

Although the NLRB is not precluded by an arbitration agreement from determining whether an unfair labor practice has been committed, NLRB v. Walt Disney Productions, 146 F.2d 44 (9th Cir. 1945), arbitrators continue to decide unfair labor practice questions under bargaining contracts containing clauses providing for arbitration of these issues. E.g., In re Int'l Harvester Co., 12 Lab. Arb. 741 (1949). Cf. Summers \& Samoff, The Labor Board Looks at Arbitration, 2 LAB. L.J. 329 (1951) and $A$ New Look at the NLRA and Arbitration, 5 id. 535 (1954), discussing the NLRB's exercise of discretion to interfere in an unfair labor practice case where arbitration has been provided for by the parties.

22. 350 U.S. 270 (1955), upholding Mastro Plastics Corp., 103 N.L.R.B. 511 (1953). 
cally prohibited would they be barred; a general statement prohibiting all strikes would be insufficient. Mastro rested in part on the protection section 13 of the Labor Management Relations Act ${ }^{23}$ affords to the right to strike when not bargained away by contract. ${ }^{24}$ But it relied as well on reasoning expressed in the Labor Board's opinion which it upheld. ${ }^{25}$ The Board had found that the parties probably did not intend to surrender a right of self-help against acts by the other which hindered contract performance and destroyed the relationship underlying the agreement. ${ }^{20}$ While both bases for the Court's decision are significant, the former would not alone have required a conclusion that the right to strike against unfair labor practices had been preserved. On the contrary, the protection derived from section 13 would have permitted a decision that the union in fact intended to bargain away the right to conduct such strikes as well as economic strikes, since the section makes no apparent distinction between the two forms of work stoppages. ${ }^{27}$ Acceptance of the Board's reasoning, however, enabled the Court to achieve the desired result of distinguishing between the effects of an express no-strike clause on different kinds of strikes. In any event Mastro clearly placed the right to strike against unfair labor practices in a preferred status. The decision accordingly should be interpreted as preserving this right unless the union expressly cedes it or substantial evidence indicates it has been bargained away.

Since the arbitration clause in Mastro was a narrow one, 28 the Supreme Court did not have to consider its effect on an unfair labor practice strike. Nevertheless, unless clearly bargained away, preservation of the right to strike in such situations should not be limited by the breadth of the arbitration clause. Although Mastro itself does not distinctly indicate how federal legislation gives such strikes a preferred status, support for this view may be found in the basic federal labor law. Section 2(3) of the Labor Management Relations Act has been judicially interpreted to enable workers engaged in such strikes to con-

23. Section 13, 61 Stat. 151 (1947), 29 U.S.C. \& 163 (1952), provides:

"Nothing in this Act, except as specifically provided for herein, shall be construed so as either to interfere with or impede or diminish in any way the right to strike, or to affect the limitations or qualifications on that right."

24. 350 U.S. at 283-84. The contract may put greater restrictions on the right to strike than does federal legislation. See Local 181, Int'l Union of Operating Engineers v. Dahlem Constr. Co., 193 F.2d 470, 474 (6th Cir. 1951).

25. 350 U.S. at 284 .

26. Mastro Plastics Corp., 103 N.L.R.B. 511, 513-15 (1953). This theory accords with the contract rule that an implied condition exists in every agreement restricting either party from affirmatively hindering performance by the other. Note, 53 CoLus. I. REv. 1023, 1025 (1953). See Patterson v. Meyerhofer, 204 N.Y. 96, 97 N.E. 472 (1912); Restatement, Contracts $\$ 295$ (1932).

27. See note 23 supra.

28. The bargaining agreement in Mastro provided that disputes as to meaning and application of the contract-including whether a strike, work stoppage or lockout had actually occurred-and disputes as to failures to maintain union membership were subject to arbitration. See 350 U.S. at 281 n.12. 
tinue as employees and gain reinstatement with back pay on termination of the strike, even if this requires discharge of replacements. ${ }^{29}$ In contrast, an employer need not oust replacements to rehire economic strikers. ${ }^{30} \mathrm{~A}$ combined reading of sections 7 and $8(d)^{31}$ of the act further indicates this greater protection. The right of employees to engage in concerted activities for mutual protection secured by section 7 may be interpreted to guarantee the right to strike ${ }^{32}$ when not relinquished by contract. ${ }^{33}$ And section $8(d)$ has been read to make illegal as a matter of law only strikes to modify a contract while it is in force. ${ }^{34}$ As a result unfair labor practice strikes should remain within the protection of section 7 when not clearly surrendered by the union.

Because of their protected position, unfair labor practice strikes should not fall within a no-strike clause implied as a matter of law from a bargaining contract's arbitration clause. Instead, when a contract includes an arbitration

29. See NLRB v. Remington Rand, Inc., 130 F.2d 919, 927-28 (2d Cir. 1942); cf. NLRB v. Thayer Co., 213 F.2d 748, 752 (1st Cir. 1954).

Section 2(3), 61 Stat. 137 (1947), 29 U.S.C. § 152(3) (1952), amending 49 Stat. 450 (1935), provides in part :

"The term 'employee' ... shall include any individual whose work has ceased as a consequence of, or in connection with, any current labor dispute or because of any unfair labor practice, and who has not obtained any other regular and substantially equivalent employment...."

30. NLRB v. Jackson Press Inc., 201 F.2d 541 (7th Cir. 1953). See NLRB v. Mackay Radio \& Tel. Co., 304 U.S. 333, 345-47 (1938).

31. Section 7, 61 Stat. 140 (1947), 29 U.S.C. \$ 157 (1952), amending 49 Stat. 452 (1935), provides:

"Employees shall have the right to self-organization, to form, join or assist labor organizations, to bargain collectively through representatives of their own choosing, and to engage in other concerted activities for the purpose of collective bargaining or other mutual aid or protection. . .."

Section S(d), 61 StAT. 142 (1947), 29 U.S.C. $\$ 158$ (d) (1952) reads in part:

" $[W]$ here there is in effect a collective-bargaining contract ... no party to such contract shall terminate or modify such contract, unless the party desiring such termination or modification-(1) serves a written notice upon the other party to the contract of the proposed termination or modification sixty days prior to the expiration date... [and] ( 4 ) continues in full force and effect, without resorting to strike or lock-out, all the terms and conditions of the existing contract for a period of sixty days after such notice is given or until the expiration date of the contract, whichever occurs later. ..."

32. Division 998, Amalgamated Ass'n of Street Elec. Ry. Employees v. Wisconsin Employment Relation Board, 340 U.S. 383, 389, 398 (1951) ; International Union, United Automobile Workers, CIO v. O'Brien, 339 U.S. 454, 457 (1950); NLRB v. John \& Ollier Engraving Co., 123 F.2d 589, 593 (7th Cir. 1941).

33. Compare NLRB v. Sands Mfg. Co., 306 U.S. 332, 339 (1939), with NLRB v. Thayer Co., 213 F.2d 748 (1st Cir. 1954), indicating that refusal to reinstate employees striking against economic terms of a contract, in contrast to unfair labor practice strikers, is not violative of rights under $\$ 7$.

34. See Mastro Plastics Corp. v. NLRB, 350 U.S. 270, 289 (1956), qualifying Local 3, Packinghouse Workers, CIO v. NLRB, 210 F.2d 325 (8th Cir. 1954). See also Note, 53 Colum. L. Rev. 1023 (1953). 
clause and an unfair labor practice strike not expressly prohibited by the contract is called, parol evidence should be admitted to indicate the intent of the parties on the scope of the arbitration clause. Here, too, the preferred status of unfair practice strikes should require the employer to prove the union gave up the right to engage in such strikes when the arbitration clause was adopted. On the other hand, the union should carry the burden of proving the strike was against an unfair labor practice. ${ }^{35}$ The employer would otherwise be compelled to negate the possibility of unfair labor practices on his part ${ }^{36}$ in order to prove the stoppage was either a strike to modify the bargaining agreement, ${ }^{37}$ or another form of strike of an economic nature to which Mead may be applicable.

This latter type of work stoppage, moreover, seems reasonably susceptible to the Mead approach. Arising from typical shop grievances such stoppageswalkouts against an employer's interpretation of his own contract powers-are acts of self-help to protest the very employer activity most clearly subject to effective arbitration. True, it may be argued that the special legislative protection afforded unfair labor practice strikes is logically applicable to grievance strikes. ${ }^{38}$ But unlike unfair practice strikes, these strikes are not occasioned by employer attempts to hinder the union's contract performance through such statutorily rejected actions as refusals to bargain or discrimination against union members. ${ }^{39}$ In agreeing to arbitrate, the union more likely meant to surrender the right to conduct such strikes than it did to refrain from unfair practice strikes.

Thus if a union has not ceded the right to strike against an employer's unfair labor practice, it should be able to defend a section 301 action on that ground. Although unfair labor practices are ordinarily within the exclusive jurisdiction of the NLRB, it would not always be necessary to refer the matter

35. For a discussion of the primary jurisdiction of the NLRB to determine unfair labor practices, see note 40 infra and accompanying text.

36. A party alleging the affirmative usually has the burden of establishing a fact which is denied. 20 Arr. Jur., Evid. $\$ 135$ (1939). See, e.g., Wood v. Auburn, $87 \mathrm{Me}$. 287, 32 A. 906 (1895). But the burden of proof is sometimes on the party asserting the negative. See 9 Wigrore, EvidencE $\$ 2485$ (3d ed. 1940).

37. See note 20 supra and accompanying text.

38. See notes 31-34 supra and accompanying text. When a collective bargaining agreement makes all disputes subject to arbitration and does not provide specifically whether an employer retains a particular power, questions of the employer's powers are arbitrable, see Bohlinger v. National Cash Register Co., 305 N.Y. 539, 114 N.E.2d 31 (1953), and these interpretations are thus not terms of the contract. Hence a strike against an employer's interpretation of his own powers would not be a strike against an economic provision of the contract as in NLRB v. Sands Mfg. Co., 306 U.S. 332 (1939), or a strike to terminate or modify contract terms within the meaning of LMRA § 8(d). See notes 20,34 supra and accompanying text.

39. See 61 Stat. 141 (1947), 29 U.S.C. \$ 158(a) (5), amending 49 Star. 453 (1935) (refusal to bargain); 61 Stat. 140 (1947), 29 U.S.C. $\$ 158$ (a) (3), amending 49 StaT. 452 (1935) (discrimination against union members). See note 26 supra and accompanying text. 
to that agency. ${ }^{40}$ Before answering the complaint the union should move to stay the proceedings pending arbitration. ${ }^{41}$ Where there is a broad arbitration clause such as that in Mead, arbitrators have been allowed to decide unfair labor practice issues. ${ }^{42}$ And arbitration provides the speediest and most efficient means of adjudication in these cases. Arbitrators, familiar with the practical and day-to-day relations of the parties, are best able to administer the con-

40. Since the defense would have to establish the employer's unfair labor practice, there are serious problems concerning the "primary jurisdiction" of the National Labor Relations Board to decide whether unfair labor practices have been committed. See Local 205, United Elec. Workers v. General Elec. Co., 231 F.2d 259, 261 (D.C. Cir. 1956), cert. denied, 25 U.S.L. WeEK 3115 (U.S. Oct. 16, 1956) ; Amalgamated Util. Workers v. Consolidated Edison Co., 309 U.S. 260, 264 (1940) (dictum). Courts normally refuse to hear cases which require them to decide such issues. Compare Local 205, United Elec. Workers v. General Elec. Co., supra, with Local 259, United Elec. Workers v. Worthington Corp., 236 F.2d 364 (1st Cir. 1956) and Independent Petroleum Workers v. Esso Standard Oil Co., 235 F.2d 401 (3d Cir. 1956). See Note, 69 Harv. L. Rev. 725 (1956). To avoid jurisdictional conflict with the Labor Board, a court implementing the text suggestion in a suit for damages similar to that in Mead could require the union to file a complaint with the Board before it could raise the unfair labor practice defense in its answer. The suit would then be stayed pending the Board's acceptance or rejection of the complaint. See LMRA \$ 10(c), 61 Stat. 147 (1947), 29 U.S.C. \$ 160(c) (1952), amending 49 STAT. 454 (1935); cf. S.S.W., Inc. v. Air Transp. Ass'n, 191 F.2d 658 (D.C. Cir. 1951), cert. donied, 343 U.S. 955 (1952) ; Note, 65 YALE L.J. 1.196, 1203 (1956). Were the complaint rejected, the union would lose the defense and the suit could proceed. Were an unfair labor practice found by the Board, the stay would be continued pending any appeal to the courts from the Board's adjudication of the unfair labor practice. See LMRA \& 10(f), 61 Stat. 148 (1947), 29 U.S.C. $\$ 160(f)$ (1952), amending 49 Stat. 455 (1935). This adjudication would later bind the court hearing the damage action. If this text proposal is adopted and if the Board itself rejects the union's complaint for lack of jurisdiction, the court would have to be permitted to decide an unfair labor practice question. Cf. Note, 69 HARv. L. REv. 725, 730 (1956). See also notes 41-44 infra and accompanying text.

41. See Signal-Stat Corp. v. Local 475, United Elec. Workers, 235 F.2d 298 (2d Cir. 1956).

Admittedly, dispute exists whether the stay provision of the United States Arbitration Act applies to collective bargaining contracts. See 9 U.S.C. $\$ 3$ (1952). Compare Tenny Engineering, Inc. v. Local 437, United Elec. Workers, 207 F.2d 450 (3d Cir. 1953) (holding expressly confined to collective bargaining contracts of employees engaged in production of gouds for interstate commerce) and Lewittes \& Sons v. United Furniture Workers, CIO, 95 F. Supp. 851 (S.D.N.Y. 1951), with Pennsylvania Greyhound Lines v. Amalgamated Ass'n of Street Elec. Ry. Employees, 193 F.2d 327, 328 (3d Cir. 1951) and International Union United Furniture Workers v. Colonial Hardwood Flooring Co., 168 F.2d 33, 38 (tth Cir. 1948) (alternative holding). See Cox, Grievance Arbitration in the Federal Courts, 67 HARv. L. REv. 591 (1954); Mendelsohn, Enforceability of Arbitration Auriements l'nder Taft-Hartley Section 301, 66 YALE L.J. 167 (1956). And the many problems of construction of federal legislation raised by a decision to grant a stay are complex. See id. at 173-76, 201.

The stay section of the United States Arbitration Act requires that the moving party himself not be in default. 9 U.S.C. $\S 3$ (1952). Since the question of whether a strike breached the contract would be an arbitrable issue under a broad arbitration clause, the court should not deem a strike per se a default of the arbitration agreement.

42. See note 21 supra. 
tract.43 Arbitrating whether the strike breached the contract would not only protect both the union and the employer but also refer the parties to a procedure they had originally agreed upon in the contract. ${ }^{44}$

43. See Signa1-Stat Corp. v. Local 475, United Elec. Workers, 235 F.2d 298, 302 (2d Cir. 1956) ; Shularan, Opinions of the UMpire, Ford Motor Co. and UAW-CiO, 1943-1946 preface (1946) ; Shulman, Reason, Contract, and the Law in Labor Relations, 68 Harv. L. Rev. 999, 1018 (1955); cf. Kaye \& Allen, Union Responsibility and the Enforcement of Collective Bargaining Agreements, 30 B.U.L. Rev. 1, 26-28 (1950) (arbitration features speed and a more efficient fact-finding procedure).

44. The arbitrator would determine whether the strike breached the contract. See Signal-Stat Corp. v. Lacal 475, United Elec. Workers, supra note 43 (action for damages for strike in alleged breach of contract stayed pending arbitration pursuant to broad arbitration clause). See also, e.g., In re Ford Motor Co., 6 Lab. Arb. 799 (1947); In re Kroger Co., 5 Lab. Arb. 154 (1946). But see Markel Elec. Products, Inc. v. United Elec. Workers, $202 \mathrm{~F} .2 \mathrm{~d} 435$ (2d Cir. 1953) (strike in alleged breach of contract not arbitrable when arbitration clause related only to meaning and application of contract in regard to wages, hours and conditions of employment).

Were it a breach, he could award damages if he thought such relief appropriate. See Lewittes \& Sons v. United Furniture Workers, CIO, 95 F. Supp. 851 (S.D.N.Y. 1951); In re Motor Haulage Co., 6 Lab. Arb. 720, aff'd, Motor Haulage Co. v. Teamsters Union, 272 App. Div. 382, 71 N.Y.S.2d 352 (1st Dep't 1947) ; cf. General Footwear Corp. v. A. C. Lawrence Leather Co., 252 N.Y. 577, 170 N.E. 149 (1929) (sales contract).

Regardless of how the arbitrator ruled on the strike issue, once a decree on the merits of the original dispute had issued, the union would no longer have a right to strike against the employer's action. A continued strike would be a breach of the arbitrator's award, which had become a term of the contract, of. Taylor, The Voluntary Arbitration of Labor Disputes, 49 MICH. L. Rev. 787, 795 (1951), and would thus be barred by the orthodox rationale against economic strikes. See note 20 supra and accompanying text. For such a breach the union should be liable further in damages. 